\title{
The social responsibility of scientists: moonshine and morals
}

\author{
Lewis Wolpert
}

If knowledge is dangerous then scientists are irresponsible. There is a long history suggesting that this is the case. The serpent in Milton's Paradise Lost refers to the' Tree of Knowledge as the "mother of science"; Prometheus was punished for bringing knowledge to the world, and Faust for wanting it too much. Are scientists responsible for the knowledge they generate and how it is used? What special responsibilities do scientists have?

There are natural duties of all citizens in our society such as to help one another and not to inflict unnecessary suffering. These duties apply to us without regard to certain voluntary choices, such as choice of career, that we have made. ${ }^{1}$ There are, by contrast, obligations that result from our having taken a particular choice, such as marrying or standing for public office. So the question is what obligations do scientists have to society as distinct from other scientists above natural duty? To what extent does the privileged knowledge that scientists have entail new obligations?

\section{A moral tale}

In 1933 The Times quoted Lord Rutherford, who had just split the atom, as saying "anyone who looked for a source of power in the transformation of atoms was talking moonshine." The Hungarian physicist Leo Szilard was staying at the Imperial Hotel, Bloomsbury, read the article, and was reminded of $\mathrm{H}$ G Wells's The World Set Free, published as long ago as 1914, in which the development of both atomic energy and an atomic bomb are described. To Szilard, pronouncements "of experts to the effect that something cannot be done" was always irritating. "This sort of set me pondering as I was walking the streets of London, and I remembered I stopped for a red light at the intersection of Southampton Row.... I was pondering whether Lord Rutherford might not be proved wrong." It was at that instant that the idea of a neutron chain reaction came to him. "I didn't see at the moment just how one would go about finding such an element, or what experiments would be needed, but the idea never left me. In certain circumstances it might be possible to set up a nuclear chain reaction, liberate energy on an industrial scale, and construct atomic bombs." 23

Szilard pursued his idea and in 1934 applied for a patent which described the laws of a chain reaction. Because of his reading of $H \mathrm{G}$ Wells he did not want the patent to become public for fear the Germans might use the idea, and so assigned it to the British Admiralty. In 1938, now living in the United States, he learned that uranium had just the properties that might sustain a chain reaction. Szilard contacted Einstein and persuaded him to write a letter to Roosevelt which was sent on 2 August 1939. "Sir, some recent work by E. Fermi and L. Szilard, which has been communicated to me in manuscript, leads me to expect that the element uranium may be turned into a new and important source of energy in the immediate future.... This new phenomenon would also lead to the construction of bombs...."

In October a British report was taken to Roosevelt and influenced the decision to proceed. It was at this stage that the policy on the future of the bomb, and any

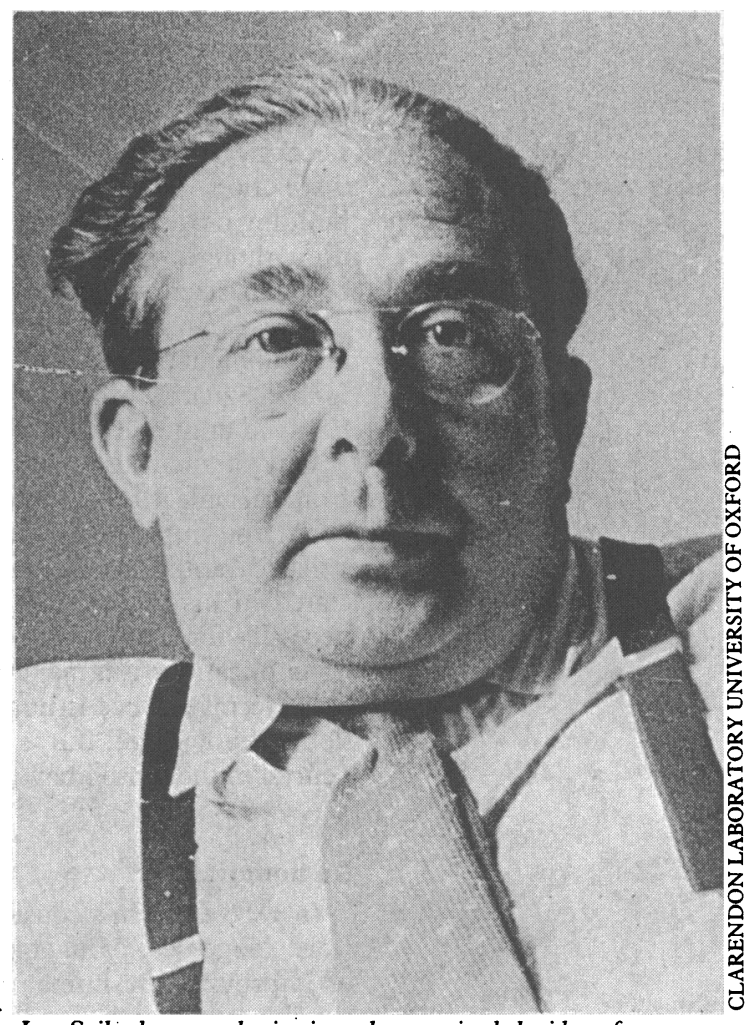

Leo Szilard, a moral scientist, who conceived the idea of a neutron chain reaction while waiting at traffic lights in Southampton Row

future decisions, moved firmly under the President's control. As Richard Rhodes writes, "from this time on, a scientist could choose to help or not to help build nuclear weapons. This was his only choice. The surrender of any further authority in the matter was the price of admission to what would grow to be a separate, secret state with separate sovereignty linked to the public state through the person and by the sole authority of the President." 2 The commitment to a thorough exploration as to whether or not to build an atomic bomb was made by Roosevelt alone.

In March 1945 Szilard began to examine the wisdom of testing bombs and using bombs. "... it was clear that the war against Germany would soon end, and so I began to ask myself 'What is the purpose of continuing the development of the bomb, and how would the bomb be used if the war with Japan has not ended by the time we have the first bombs?" The initial motivation of getting ahead of the Germans was no longer there. He drafted a memorandum for Roosevelt. But Roosevelt died in May and it was Truman's Secretary of State, James Byrnes, who met Szilard. He argued that Congress would want results for its $\$ 2 \mathrm{bn}$ investment, and not to test was not an option. Also, having a bomb might make the Russians "more manageable."

The bomb was successfully tested in July, and Szilard was already circulating among the Manhattan Project scientists a petition to present to President Truman. It started:

"Discoveries of which the people of the United States are not aware may affect the welfare of this 
nation in the near future." It continued by arguing against the use of the bomb now that there was no danger of the enemy using it against the United States. It never reached the president.

The bomb was dropped on Hiroshima on 6 August. Szilard wrote to a friend: "Using atomic bombs against Japan is one of the greatest blunders in history."

The bomb can be regarded as a triumph of engineering. Many, many scientists and engineers were involved. The technology was amazing, but at heart it was merely a gigantic superstructure to make Szilard's basic idea work.

There are many lessons to be learnt from this moral tale. Szilard was a moral scientist and a moral citizen. The decision to build the bomb was a political, not a scientific, decision. It also makes very clear the distinction between science and technology. The building of the bomb was a technological achievement even though it used scientific knowledge. The gap between scientific knowledge and application was in this case enormous. For those who would blame the development of the bomb on science I must ask them to follow Szilard through the story and show how he behaved immorally.

One of the most important obligations to emerge from this tale is that of openness and telling the public about the implications of scientific knowledge. It is Szilard's emphasis on public involvement so clearly stated in his petition that we should focus on. The necessity for the public to be informed on science and its implications is a major obligation for scientists. In these terms science is not responsible for misapplication of knowledge. But is all knowledge beautiful and neutral in the sense I have suggested?

\section{An immoral tale}

In 1883 Darwin's cousin Francis Galton coined the word "eugenics." "Eugenics was defined as the science of improving the human stock by giving "the more suitable races or strains of blood a better chance of prevailing speedily over the less suitable." For Galton science and progress were almost inseparable. Men could be improved by scientific methods, in the manner that plant breeders improved their stock. Would it not, he wondered, be "quite practicable to produce a highly gifted race of men by judicious marriages during several consecutive generations." The scientific assumptions are explicit: human characters are inherited. ${ }^{4}$

These ideas, amplified by Karl Pearson, received support from various sources which included Fabians like Bernard Shaw and psychologists like Havelock Ellis. An American, Charles Davenport, was particularly influenced by the eugenic ideas and in 1904 persuaded the Carnegie Foundation to set up the Cold Spring Harbor Laboratories for the study of human evolution. Davenport came to believe that certain races were feebleminded from his studies on human pedigrees. Negroes were biologically inferior; Poles were perceived of as "independent and self-reliant though clannish"; the Italians tended to "crimes of personal violence." He expected the American population to become through immigration "darker in pigmentation, smaller in stature, more mercurial ... more given to crimes of larceny, kidnapping, assault, murder, rape and sex-immorality." His aim was to promote negative eugenics-preventing proliferation of the bad. To this end he favoured a selective immigration policy to prevent the contamination of the germ plasm from without, and to deal with internal "badness" he tried to prevent reproduction of those he considered genetically defective.

Davenport's approach to human genetics was in terms of single mendelian traits, though he knew of polygenic inheritance. Thus he suggested that prostitution was due to an "innate eroticism." Yet Davenport saw himself as a scientist who wished to base his ideas on sound investigations. Thousands of Americans were persuaded to fill out their "record of family traits" and send them to Davenport.

There was a reaction by the biologists to many of the wilder claims for eugenics. But, in a way it was too late. For as Müller-Hill writes: "The ideology of the National Socialists can be put very simply. They claimed that there is a biological basis for the diversity of mankind. What makes a Jew a Jew, a Gypsy a Gypsy, an asocial individual asocial, and the mentally abnormal abnormal, is in their blood, that is to say in their genes."'

It is hard not to believe that this was based on the genetic ideas of the eugenic movement. For example, Professor Fischer, a professor of anthropology and rector of the University of Berlin, a promulgator of such views, was asked by Davenport in 1929 to become chairman of the committee on racial crosses of the International Federation of Eugenics Organisations. One can trace a direct line from the eugenics movement to the statement by Konrad Lorenz: "it must be the duty of racial hygiene to be attentive to a more severe elimination of morally inferior human beings than is the case today...."

In 1933 Hitler's cabinet promulgated a eugenic sterilisation law, which can be considered as leading directly to the atrocities of the concentration camps.

I am not concerned here with the reasons for the behaviour of the doctors in the concentration camps. Doctors, in general, are not scientists. They are technologists, like engineers. What we have to consider is the responsibility of the scientists who effectively laid the foundation for the genetic theories that underlay the cruder versions of biological determinism. One cannot simply dismiss them by saying they were bad scientists, for the question of biological determinism in the form of sociobiology is very much still with us. What is at issue is how scientists should handle delicate issues like race and intelligence. Is research into such areas legitimate? Or are there, as George Steiner has argued "certain orders of truth which would infect the marrow of politics and would poison beyond all cure the already tense relations between social classes and ethnic communities"? In short, there are doors immediately in front of current research which are marked "too dangerous to open."

The scientists who promoted the views of the eugenics movements may have been honourable with respect to their science; they could perhaps plead genuine ignorance or error in dealing with the data. But they completely failed to critically examine the social implications of their conclusions. Quite the contrary: their conclusions seem to have been driven by what they saw as their desirable social implications.

\section{Obligations over the implications}

Scientists have the obligation to examine the social implications of their work, not to decide how or if it should be used - that, as in the case of the bomb, is a political decision-but to make it clear how reliable their conclusions are. In some areas of science it matters little to the public whether a particular theory is flawed or even wrong. By contrast it matters a great deal if as in the case of human genetics behavioural characteristics are treated as simple mendelian traits. Scientists have an obligation to make the reliability of their conclusions in these areas clear to the point of tediousness. This is particularly true of ideas such as those suggested by some sociobiologists, which, as Kitcher says, "foster the idea that class structures are 
socially inevitable, the aggressive impulses towards strangers are part of our evolutionary heritage, and that there are ineradicable differences between the sexes that doom women's hope for genuine equality." 6

They should imagine themselves, perhaps, according to Rawls, ${ }^{1}$ in the original position in which the rules for society are being set up. However, none of the parties knows his or her place in society - there is a veil of ignorance. The parties do not know their sex, natural abilities, or even the generation to which they belong. They are brought together to agree detailed rules based on a general principle of justice. All social values-liberty and opportunity, income and wealth, and the bases of self respect-are to be distributed equally unless an unequal distribution of any, or all, of these values is to everyone's advantage. The scientists should then consider the conviction they would give to their conclusions in such a situation. Would those who believe with deep conviction in the natural inferiority of women or certain races maintain that conviction knowing that he or she might belong to one of those groups?

The response might surprisingly be yes. For this could well lead to the distribution of, say, jobs or money to disadvantaged groups, in excess of advantaged groups, if it were established that they were disadvantaged. They may be given preferential treatment. But we do not live in such an idealised world. In our real world conclusions about human behaviour and racial differences can feed current prejudices and have a severe negative influence.

Provided the obligation to make the reliability of the research clear and public is fulfilled then the answer to Steiner must be that there are no areas which ought not to be subject to research.

\section{Scientists and social responsibility}

Many people will not be persuaded by the sharp distinction I draw between scientific knowledge and its application - between science and technology. In these terms doctors are to biologists as engineers are to physicists. This is not a question of purity or snobbery but of implementation. Nevertheless, there are areas where the boundaries may not appear to be very sharp, as in the case of the application of genetic engineering and gene therapy.

It is now possible to insert genes into human cells. The introduction of genes into somatic cells does not raise any new ethical issue since the introduction of new genetic material is routinely done with organ and bone marrow transplants. The problem of safety, particularly if viruses are used, seems to be no different to that in any new medical treatment. Even for the introduction of genes into the germline, which does raise difficult issues, it is not for the scientist or the doctors to decide on the wisdom or otherwise of such a procedure. The obligation of the scientist and the doctor is to spell out the implications of such procedures.

There is a real danger in asking scientists to be more socially responsible - the history of eugenics alone should show at least some of the dangers. For, by asking scientists to be socially responsible, in terms other than the obligations already discussed, would be to give power to a group who are neither trained nor competent to exert it. It was not for scientists to decide whether or not to build a bomb. Nor will it be for scientists and doctors alone to decide whether or not to introduce genes into the germlines.

For those who doubt whether the public, or the politicians, are capable of taking the correct decisions I would urge them to follow Thomas Jefferson: "I know no safe depository of the ultimate powers of the society but the people themselves, and if we think them not enlightened enough to exercise that control with a wholesome discretion, the remedy is not to take it from them, but to inform their discretion." When the public are gene literate these problems will seem no different in principle from those such as euthanasia and abortion, which are not obfuscated by an alienating scientific ignorance. That is not to say that other obfuscations are not present, but that is another issue.

It is also important not to give the public the impression that science can solve all problems. Certain problems may be, in principle, intractable. It is unwise to assume, for example, that health services research, as suggested by the select committee of the House of Lords, will solve the major problems of providing health care. It is also important to remember that as Paul Valery said, "We enter the future backwards." Today's moonshine is tomorrow's technology. And with technology comes responsibility.

Perhaps scientists should try to follow Szilard's first commandment: "Recognize the connection of things and the laws of conduct of men, so that you may know what you are doing."

1 Rawls J. A theory of justice. Oxford: Oxford University Press, 1972.

2 Rhodes R. The making of the atomic bomb. New York: Simon and Schuster, 1986

3 Weast SR, Szilard GW. Leo Szilard: his version of the facts. Cambridge: Massachusetts: MIT Press, 1978

4 Kevles DJ. In the name of eugenics. Berkeley: University of California Press, 1985.

5 Müller-Hill B. Murderous science. Oxford: Oxford University Press, 1988. 6 Kitcher P. Vaulting ambition. Cambridge, Massachusetts: MIT Press, 1985.

\section{ANY QUESTIONS}

Are generic products routinely tested by government agencies for quality and efficacy?

When a company applies for a product licence to market a completely new drug it has to supply the regulatory authority with both pharmaceutical and therapeutic data. The licensing authority has to be satisfied about the quality of the drug substance itself and the formulation, the bioavailability in volunteers and patients, and the clinical performance of the drug. The supplier of a generic drug must also obtain a product licence and must satisfy the licensing authority about the quality of the drug substance and the formulation. The authority must also be satisfied that the bioavailability of the generic drug is equal to that of the original brand product. This is normally based on in vitro data, but in vivo studies in normal volunteers are requested for drugs when "inequivalence would subject patients to risk" - for example, drugs with a narrow therapeutic margin or drugs such as anticonvulsants, where there is a hazard to the patient from inefficacy. Data on clinical performance (including efficacy and side effects) are not required. The manufacturer of a generic drug, who may not be the supplier, must also have a licence, and this is granted only if the Department of Health's medicines inspectorate is satisfied that the manufacturer's premises and procedures meet the required standards. These requirements ensure that most generic drugs in the United Kingdom are satisfactory. They are probably not adequate, however, to prevent the occasional generic product failing to come up to standard. There are enough examples of differences between products to justify concern about quality control of some generic products. - LINDA BEELEY, consultant clinical pharmacologist, Birmingham

Anonymous. For and against generic prescribing. Drug Ther Bull 1987;25:23-95.

Carter MG, Sanderson JH. Generic prescribing and clinical bioinequivalence. Pharmaceutical fournal 1988;683-4. 